\title{
Dampak Pertambangan Batubara Terhadap Sosial dan Ekonomi Masyarakat di RT. 17, Desa Loa Duri Ulu, Kecamatan Loa Janan, Kabupaten Kutai Kartanegara
}

\author{
Fachruddin Azwari \\ Pengelolaan Lingkungan, Politeknik Pertanian \\ Negeri Samarinda, Samarinda, Indonesia \\ fahriazwari@politanisamarinda.ac.id \\ *Corresponding Auhtor
}

\author{
Arini Rajab \\ Pengelolaan Lingkungan, Politeknik Pertanian \\ Negeri Samarinda, Samarinda, Indonesia \\ arinirajab@gmail.com
}

\begin{abstract}
Abstrak - Penelitian ini dilatarbelakangi oleh banyaknya kegiatan pertambangan batubara yang ada di di Kabupaten Kutai Kartanegara yang berdampak langsung terhadap kehidupan sosial dan ekonomi masyarakat. Kegiatan pertambangan batubara tersebut tentu akan mengakibatkan dampak positif dan negatif, baik terhadap lingkungan, maupun ke masyarakat sekitar yang bersifat ekonomis dan sosial. Salah satu penyebabnya yaitu terjadinya proses konflik sosial atau perubahan tatanan kehidupan dalam bermasyarakat, dimana terjadi pola perubahan pekerjaan dari masyarakat yang hidupnya bertani atau berdagang menjadi karyawan perusahaan. Oleh karena itu tujuan dari penelitian ini adalah untuk mengetahui dampak sosial dan ekonomi yang dirasakan masyarakat sekitar tambang dan mengetahui peran serta perusahaan tambang dalam peningkatan kesejahteraan masyarakat Hasil penelitian didapatkan bahwa dari hasil penyebaran angket kuesioner, perubahan cukup signifikan antara lain didapatkan yaitu peningkatan ketersediaan prasarana pendidikan, peningkatan kualitas tenaga pendidik. di bidang kesehatan juga menunjukkan adanya peningkatan pemberdayaan kesehatan kepada masyarakat. di bidang tenaga kerja terjadi penyerapan tenaga kerja yang cukup banyak di wilayah tersebut dan adanya prioritas terhadap tenaga kerja lokal.
\end{abstract}

Kata Kunci - Pertambangan, Batubara, Social, Ekonomi, Loa

\section{PENDAHULUAN}

Indonesia merupakan negara yang kaya akan sumberdaya alam. Sumberdaya alam merupakan sumberdaya yang esensial bagi kelangsungan hidup manusia. Hilangnya atau berkurangnya ketersediaan sumberdaya tersebut akan berdampak sangat besar bagi kelangsungan hidup umat manusia di muka bumi. Kekayaan sumberdaya alam Indonesia ini pula yang menyebabkan negara kita dijajah selama berabad-abad oleh negara Belanda dan juga selama tiga setengah tahun oleh negara Jepang.

Salah satu sumberdaya alam yang kita miliki adalah batubara, yang termasuk sumberdaya alam yang paling berguna saat ini, baik untuk industri dalam negeri maupun industri luar. Sektor pertambangan merupakan salah satu andalan untuk mendapatkan devisa dalam rangka kelangsungan pembangunan negara. Di bumi Etam ini, sumberdaya alamnya pun melimpah, diantaranya batubara, kayu, dan lain-lain. Kalimantan Timur terdapat banyak sekali perusahaan Pertambangan Batubara, salah satunya PT. Bukit Baiduri Energi (Bukit Baiduri Energi) yang merupakan perusahaan pemilik lahan pertambangan batubara, yang memiliki beberapa kontraktor sebagai partner dalam melakukan penambangan. Di sekitar perusahaan ini dilakukan penelitian mengenai dampak langsung ataupun tidak langsung terhadap keadaan sosial dan ekonomi masyarakat di sekitar lingkungan tambang milik PT. Bukit Baiduri Energi ini.

Kegiatan pertambangan pada dasarnya merupakan proses pengalihan sumberdaya alam menjadi modal nyata ekonomi bagi negara dan selanjutnya menjadi modal sosial. Modal yang dihasilkan diharapkan mampu meningkatkan nilai kualitas insan bangsa untuk menghadapi hari depannya secara mandiri. Dalam proses pengalihan tersebut perlu memperhatikan interaksi antara faktor sosial, ekonomi, dan lingkungan hidup sehingga dampak yang terjadi dapat diketahui sedini mungkin.

Penelitian dilakukan di sekitar perusahaan milik PT. Bukit Baiduri Energi. Apakah kegiatan penambangan batubara di daerah tersebut memberi dampak sosial dan ekonomi terhadap masyarakat? Bagaimanakah peran serta perusahaan terhadap keadaan peningkatan kesejahteraan sosial dan ekonomi masyarakat sekitar? Dari pertanyaan tersebut, maka dicoba untuk terjun langsung ke masyarakat sektor pertambangan batubara, guna mengumpulkan informasi.

Adapun tujuan dari penelitian ini yaitu mengetahui dampak sosial dan ekonomi yang dirasakan masyarakat sekitar tambang dan mengetahui peran serta perusahaan tambang dalam peningkatan kesejahteraan masyarakat.

Penelitian ini diharapkan mampu memberikan gambaran bahwa keberadaan perusahaan tambang di sekitar lingkungan masyarakat akan berdampak pada pertumbuhan sosial ekonomi masyarakat tersebut. Walaupun ada juga dampak negatif yang dirasakan oleh masyarakat karena limbah dan kerusakan lingkungan, akan tetapi masyarakat juga tertolong sebab perusahaan tersebut memberikan kesempatan kerja bagi masyarakat. 


\section{STUDI PUSTAKA}

Pertambangan batubara di Indonesia telah berlangsung selama 40 tahun lebih, sejak keluarnya UU No.11 tahun 1967 tentang pokok-pokok Pertambangan yang kemudian diganti dengan UU Pertambangan Mineral dan Batubara Tahun 2009. UU ini telah menjadi landasan eksploitasi sumberdaya mineral dan batubara secara besar-besaran untuk mengejar pertumbuhan ekonomi. Industri batubara Indonesia telah berkembang dengan pesat dalam waktu singkat. Dalam hanya 10 tahun produksi telah berkembang dari sekitar 3 juta ton menjadi lebih dari 50 juta ton, dan diharapkan dua kali lipat lagi dalam beberapa tahun mendatang. Sebagai akibatnya industri batubara menghasilkan manfaat sosial dan ekonomi yang besar bagi Indonesia seperti: lapangan kerja bagi ribuan masyarakat Indonesia terutama di daerah yang kurang berkembang di daerah seperti Kalimantan dan Sumatera dan juga akan mendukung program pemerintah untuk pengentasan kemiskinan. Namun kegiatan tersebut tidak hanya menguntungkan dari segi sosial dan ekonomi tapi juga memberikan dampak negatif, terutama kerusakan lingkungan di daerah penghasil tambang (Setiawan, 2010).

Di daerah penghasil barang tambang, lingkungan yang sehat dan bersih merupakan hak asasi setiap orang menjadi barang langka. Bahkan daerah penghasil juga merasakan ketidakadilan seperti kebutuhan energi akan listrik dari batubara masih kurang pasokannya. Sementara batubara dikirim ke daerah lain untuk memenuhi kebutuhan energi terutama untuk pembangkit listrik tenaga uap di Jawa. Di samping, itu negara Indonesia ingin meningkatkan pertumbuhan ekonominya dengan mendapatkan devisa sebesar-besarnya dari bahan tambang dan migas maka tidak ada jalan lain, eksploitasi besar-besaran terutama barang tambang batubara pada beberapa tahun ini semakin gencar. Hal ini membuat kondisi lingkungan di daerah penghasil batubara semakin menurun bahkan makin kritis (Setiawan, 2010).

Salah satu daerah penghasil batubara adalah kota Samarinda yang terletak di daerah katulistiwa. Dengan kondisi topografi yang datar dan berbukit antara 10-200 meter di atas permukaan laut dengan luas wilayah 718 $\mathrm{km}^{2}$. Kota Samarinda berbatasan dengan Kabupaten Kutai Kartanegara di sebelah Barat, Timur, Selatan dan Utara yang merupakan penghasil batubara terbesar kedua di Kalimantan Timur. Pada dasawarsa tahun 2000-an, perkembangan peningkatan produksi batubara di Kota Samarinda semakin meningkat. Sehingga Samarinda juga dikenal dengan sebutan kota tambang karena hampir $38.814 \mathrm{Ha}(54 \%)$ dari total $71.823 \mathrm{Ha}$ luas Kota Samarinda merupakan areal tambang batubara. Pertambangan batubara yang sudah berproduksi dengan rincian $38 \mathrm{KP}$ (Kuasa Pertambangan) yang mendapat ijin dari Walikota Samarinda dan 5 (lima) PKP2B2 (Perusahaan Pemegang Perjanjian Karya Perjanjian Usaha Pertambangan) dengan izin pemerintah pusat yang belum beroperasi (Anonim, 2009).

Belum lagi ada puluhan tambang-tambang illegal yang banyak dikelola pengusaha dan masyarakat. Bahkan sekarang kegiatan pertambangan ini telah merambah kawasan lindung maupun perkotaan. Hal ini diketahui setelah adanya bukti-bukti bahwa kawasan Hutan Raya Bukit Soeharto telah dirambah pertambangan batubara dan penambangan illegal yang dikenal dengan batubara karungan yang banyak terdapat di kawasan perumahanperumahan penduduk di kota Samarinda. Hal ini tentu saja makin memperparah kondisi lingkungan kota Samarinda (Setiawan, 2010).

Berbagai dampak potensial di sektor sosial dan ekonomi dapat terjadi akibat adanya penambangan batubara di suatu wilayah, baik dampak positif maupun dampak negatif. Berbagai dampak positif diantaranya tersedianya fasilitas sosial dan fasilitas umum, kesempatan kerja karena adanya penerimaan tenaga kerja, meningkatnya tingkat pendapatan masyarakat sekitar tambang, dan adanya kesempatan berusaha. Di samping itu dapat pula terjadi dampak negatif diantaranya muncul berbagai jenis penyakit akibat menurunnya kualitas udara, meningkatnya kecelakaan lalu lintas, dan terjadinya konflik sosial saat pembebasan lahan (Raden, 2010).

Melihat pertumbuhan produksi batubara dari tahun ke tahun yang semakin besar, maka diperkirakan dalam jangka waktu 10 sampai 20 tahun ke depan deposit batubara ini akan habis yang dapat berdampak negatif terhadap kondisi sosial dan ekonomi masyarakat sekitar, terutama masyarakat yang menggantungkan kehidupannya pada kegiatan pertambangan, di mana mereka akan kehilangan mata pencaharian sebagai akibat dari berhentinya beroperasi kegiatan pertambangan (Raden, 2010).

Mata pencaharian masyarakat di sekitar lokasi kuasa pertambangan PT. Bukit Baiduri Energi (Bukit Baiduri Energi) sebagian besar bekerja sebagai karyawan di perusahaan tersebut, tetapi ada juga yang bekerja sebagai petani dan buruh konstruksi.Kehidupan sosial bermasyarakat tingkat kerjasama antara warga masyarakat setempat dengan warga diluar kelompok dan dengan suku lain pada umumnya mereka mengaku dapat bekerja sama dengan kelompok atau suku lain, dengan alasan sangat menguntungkan karena dapat membuka wawasan lebih luas dan dapat bertukar pengalaman. Bentuk kerjasama yang mereka lakukan pada umumnya di bidang perburuhan, pertanian, dan ada juga yang sekedar bergaul saja. Di dalam lokasi penelitian sosial nampak beberapa warga tidak melakukan asimilasi (kawin) dengan masyarakat dari suku atau kelompok lainnya. Hal itu telah berlangsung lama dan cenderung semakin banyak warga yang melakukan kawin antar suku tersebut, karena daerah ini telah sangat terbuka dan berkembang menjadi daerah pinggiran kota. Dalam kaitannya dengan kelembagaan sosial kemasyarakatan yang masih berfungsi dengan baik pada daerah penelitian adalah berupa kelompok tani, Koperasi Unit Desa (KUD), Posyandu, Rukun Kematian dan Rukun Pengajian (Wicaksono, 2006). 


\section{METOdOLOGi PENELITIAN}

Penelitian ini dilaksanakan di sekitar perusahaan tambang batubara milik PT. Bukit Baiduri Energi, tepatnya di pemukiman penduduk yang berlokasikan di RT. 17 Desa Loa Duri Ulu, Merandai.

A. Waktu Penelitian

Penelitian ini membutuhkan waktu selama 2 bulan meliputi pengambilan data berupa pengumpulan informasi dari masyarakat yang berdomisili di RT. 17 Desa Loa Duri Ulu dan penyusunan laporan tentang dampak yang diperoleh karena adanya pertambangan batubara di daerah tersebut.

B. Alat dan Cara Kerja

1. Alat

Alat yang digunakan dalam penelitian ini yaitu:

- Kamera Digital, untuk mengambil obyek foto yang diteliti.

- Angket/kuesioner yang akan diisi oleh masyarakat sekitar.

- $\quad$ ATK untuk mencatat hasil wawancara.

2. Cara Kerja

Cara kerja untuk melakukan penelitian yaitu:

- Survei lokasi pemukiman penduduk yang akan diteliti.

- Menentukan tempat penduduk yang akan diambil sebagai sampel.

- Membagi angket/kuesioner kepada penduduk.

- Wawancara terhadap Ketua RT dan masyarakat.

- Pengambilan gambar/foto di sekitar tempat yang akan diteliti.

- Melakukan pengumpulan data dari angket/kuesioner.

C. Metode Pengambilan Sampel

Penentuan jumlah sampel, dihitung dengan mengadaptasi rumus dari Taro Yamane dalam Riduwan (2005), yaitu:

$$
n=\frac{N}{N\left(d^{2}\right)+1}
$$

Dimana:

$$
\begin{array}{ll}
\mathrm{n} & =\text { Jumlah sampel } \\
\mathrm{N} & =\text { Jumlah Kepala Keluarga } \\
d^{2} & =\text { presisi yang ditetapkan }
\end{array}
$$

Penentuan presisi sampel $\left(d^{2}=10 \%\right)$, diputuskan dengan pertimbangan populasi yang menjadi fokus penelitian bersifat seragam.

Menurut Singarimbun, dkk. (1989), makin seragam populasi pada suatu wilayah studi, maka makin kecil sampel yang dapat diambil dan dianggap representatif untuk menjawab kebutuhan analisis. Oleh sebab itu, keputusan presisi $10 \%$ untuk calon responden yang bersifat seragam dinilai sesuai.

D. Metode Pengumpulan Data

Pengumpulan data penelitian dilakukan dengan 2 (dua) cara, yaitu:

\section{Data primer}

Data primer, ialah data yang diperoleh langsung dari sumbernya, diamati dan dicatat dengan melalui kegiatan penyebaran kuisioner, wawancara, dan pengamatan lapangan. Penjabarannya sebagai berikut:

a. Penyebaran Kuesioner

Pengumpulan data melalui kuesioner yang disebarkan, dilakukan pada warga RT. 17 dengan tujuan untuk memperoleh data mengenai dampak pertambangan batubara terhadap sosial ekonomi masyarakat. Penyebaran kuesioner digunakan dalam rangka pengambilan data untuk kebutuhan analisis persepsi warga. Pada prakteknya, penyebaran kuesioner ini dilakukan dengan menggunakan teknik kombinasi pada wawancara semi terstruktur.

b. Wawancara

Pengumpulan data dengan metode wawancara dikenakan terhadap Ketua RT. 17, Desa Loa Duri Ulu. Wawancara dilakukan untuk memperoleh data sekunder untuk kebutuhan analisis yang mengharuskan perlunya wawancara.

\section{c. Dokumentasi Foto}

Pengumpulan data melalui dokumentasi foto selain sebagai bukti penelitian juga dapat menjadi kebutuhan analisis khususnya pada variabel biofisik.

\section{Data sekunder}

Data sekunder, ialah data yang diperoleh dari survei instansi atau departemen yang berhubungan dengan materi penelitian. Adapun tokoh masyarakat yang di survei yaitu Ketua Rukun Tangga (RT) 17, Desa Loa Duri Ulu.

Untuk analisis persepsi dan perilaku masyarakat, populasi dalam penelitian ini adalah masyarakat yang bermukim di sekitar RT. 17 Desa Loa Duri Ulu. Pengambilan sampel dari populasi masyarakat dilakukan secara probability yaitu teknik pengambilan sampel yang memberikan peluang sama bagi setiap unsur (anggota) populasi yang dipilih menjadi anggota sampel. Dalam penelitian ini, digunakan sampling area (cluster) atau sampling menurut daerah.

\section{E. Pengolahan Data}

Penelitian menggunakan metode kualitatif, salah satunya yaitu dengan penelitian studi kasus. Penelitian studi kasus adalah studi yang mengeksplorasi suatu masalah dengan batasan terperinci dan menyertakan berbagai sumber informasi. Penelitian ini dibatasi oleh waktu dan tempat, dan kasus yang dipelajari berupa program, peristiwa, aktivitas, atau individu. Disini peneliti juga sebagai alat utama pengumpul data yaitu dengan metode pengumpulan data berdasarkan pengamatan dan wawancara. Teori ini diterapkan bersifat dari dasar. Dengan data yang diperoleh dari penelitian di lapangan dapat dirumuskan sebagai kesimpulan atau teori dan bukan angka.

Dalam penelitian kualitatif, jumlah sampel tidak perlu banyak karena tujuannya adalah untuk menganalisis lebih mendalam mengenai sebuah fenomena atau kejadian. Tidak ada patokan khusus jumlah sampel untuk penelitian kualitatif. Selain karena metode pengumpulan datanya 
yang menggunakan observasi, wawancara dan diskusi yang tentu saja memerlukan waktu yang panjang, sehingga tidak dimungkinkan untuk mengambil sampel yang terlalu banyak (Hendry, 2012).

\section{HASIL DAN PEMBAHASAN}

Hasil penelitian yang dilakukan pada lokasi pemukiman penduduk sekitar pertambangan batubara milik PT. Bukit Baiduri Energi, dengan wawancara langsung terhadap Ketua RT 17 Desa Loa Duri Ulu, Merandai, yaitu Bapak Arfandi dan dengan membagikan kuesioner kepada sepuluh warga di wilayah itu, maka dapat dijabarkan dampak pertambangan batubara terhadap keadaan sosial dan ekonomi masyarakat sebagai berikut:

Tabel 1. Hasil Kuesioner dari 10 Responden

\begin{tabular}{|c|l|c|c|c|c|c|}
\hline No. & \multicolumn{1}{|c|}{ Pernyataan } & SS & S & KS & TS & STS \\
\hline 1. & $\begin{array}{l}\text { Ketersediaan prasarana pendidikan } \\
\text { bertambah }\end{array}$ & 4 & 6 & & \\
\hline 2. & $\begin{array}{l}\text { Terjadi peningkatan kualitas tenaga } \\
\text { pendidik }\end{array}$ & 1 & 9 & & & \\
\hline 3. & $\begin{array}{l}\text { Kemampuan untuk memenuhi uang sekolah } \\
\text { anak lebih baik }\end{array}$ & $\begin{array}{l}\text { Kemampuan untuk membeli buku-buku } \\
\text { pelajaran anak lebih baik }\end{array}$ & 10 & & & \\
\hline 4. & $\begin{array}{l}\text { Kebutuhan-kebutuhan lainnya untuk anak di } \\
\text { sekolah dapat dipenuhi }\end{array}$ & & & & \\
\hline 5. & $\begin{array}{l}\text { Ketersediaan prasarana kesehatan } \\
\text { bertambah }\end{array}$ & & & & \\
\hline 7. & $\begin{array}{l}\text { Perusahaan memberikan pemberdayaan } \\
\text { kesehatan kepada masyarakat }\end{array}$ & 3 & 7 & & & \\
\hline 8. & $\begin{array}{l}\text { Terjadi peningkatan kualitas tenaga } \\
\text { kesehatan }\end{array}$ & & 10 & & \\
\hline
\end{tabular}

Tabel 2. Dampak Ekonomi setelah kehadiran pertambangan batubara

\begin{tabular}{|c|c|c|c|c|c|c|}
\hline No. & Pernyataan & SS & $\mathrm{S}$ & KS & $\mathrm{TS}$ & STS \\
\hline 1. & $\begin{array}{l}\text { Usaha pertambangan batubara membuka } \\
\text { kesempatan kerja yang cukup besar di daerah } \\
\text { ini }\end{array}$ & & 10 & & & \\
\hline 2. & $\begin{array}{l}\text { Tingkat penyerapan tenaga kerja pada usaha } \\
\text { pertambangan batubara di daerah ini cukup } \\
\text { tinggi }\end{array}$ & 4 & 6 & & & \\
\hline 3. & $\begin{array}{l}\text { Tenaga kerja lokal mendapat prioritas untuk } \\
\text { bekerja di perusahaan }\end{array}$ & 3 & 7 & & & \\
\hline 4. & $\begin{array}{l}\text { Upah yang diterima karyawan perusahaan } \\
\text { sesuai dengan harapan masyarakat }\end{array}$ & & 10 & & & \\
\hline 5. & $\begin{array}{l}\text { Pertambangan batubara mengakibatkan } \\
\text { peningkatan aktivitas usaha yang telah ada di } \\
\text { daerah ini }\end{array}$ & & 10 & & & \\
\hline 6. & $\begin{array}{l}\text { Usaha pertambangan batubara meningkatkan } \\
\text { hasil responden }\end{array}$ & & 5 & 5 & & \\
\hline 7. & $\begin{array}{l}\text { Pertambangan batubara menumbuhkan } \\
\text { peluang usaha lain bagi masyarakat di desa ini }\end{array}$ & & 10 & & & \\
\hline 8. & $\begin{array}{l}\text { Perusahaan melakukan } \text { program } \\
\text { pengembangan ekonomi masyarakat di desa } \\
\text { ini }\end{array}$ & & 10 & & & \\
\hline
\end{tabular}

Berdasarkan data penduduk yang didapatkan melalui wawancara langsung dengan Ketua RT. 17, diketahui bahwa jumlah penduduk untuk wilayah RT. 17 mencapai 105 Kepala Keluarga (KK), dimana laki-laki berjumlah 159 orang dan perempuan berjumlah 116 orang. Adapun sarana umum yang terdapat di RT. 17 Desa Loa Duri Ulu dapat dilihat pada tabel 3 
Tabel 3. Sarana di RT. 17 Desa Loa Duri Ulu, Merandai

\begin{tabular}{|c|c|c|}
\hline No. & Keterangan & Jumlah \\
\hline 1. & \begin{tabular}{ll}
\multicolumn{2}{l}{ Sekolah } \\
- & TK \\
- & SD \\
- & SMP \\
- & SMA \\
- & Perguruan Tinggi \\
\end{tabular} & $\begin{array}{l}1 \\
1 \\
- \\
- \\
-\end{array}$ \\
\hline 2. & \begin{tabular}{ll}
\multicolumn{2}{l}{ Rumah Ibadah } \\
- & Mesjid \\
- & Langgar \\
- & Gereja
\end{tabular} & $\begin{array}{l}2 \\
2 \\
4\end{array}$ \\
\hline
\end{tabular}

Berikut ini merupakan grafik yang menunjukkan persentase antara masyarakat yang bekerja dan tidak bekerja beserta pembagian pekerjaan berdasarkan jenis pekerjaan yang dimiliki oleh masyarakat:

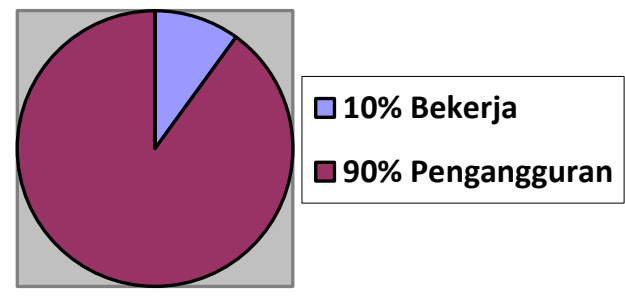

Gambar 1. Persentase Antara Masyarakat Yang Bekerja Dan Tidak Bekerja

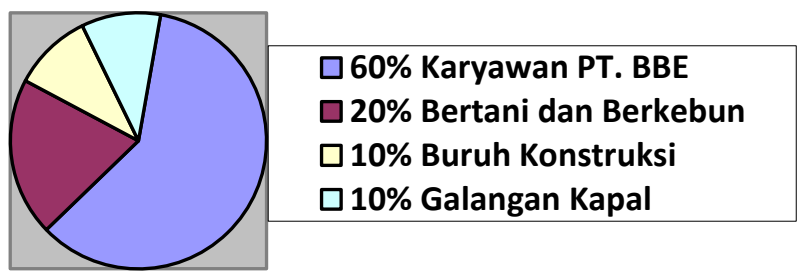

Gambar 2. Pekerjaan warga Desa Loa Duri Ulu, Merandai

Dibawah ini merupakan grafik yang menunjukkan presentase tingkat pendidikan masyarakat di RT. 17 Desa Loa Duri Ulu.

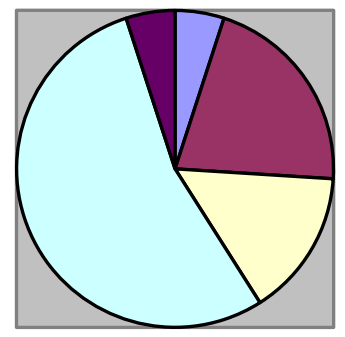

\begin{tabular}{|c|}
\hline$\square 5 \%$ Tidak \\
Sekolah \\
$\square 21 \%$ SD \\
\hline
\end{tabular}

Gambar 3. Tingkat pendidikan warga RT. 17 Desa Loa Duri Ulu
Dibawah ini merupakan grafik yang menunjukkan presentase tingkat usia masyarakat di RT. 17 Desa Loa Duri Ulu

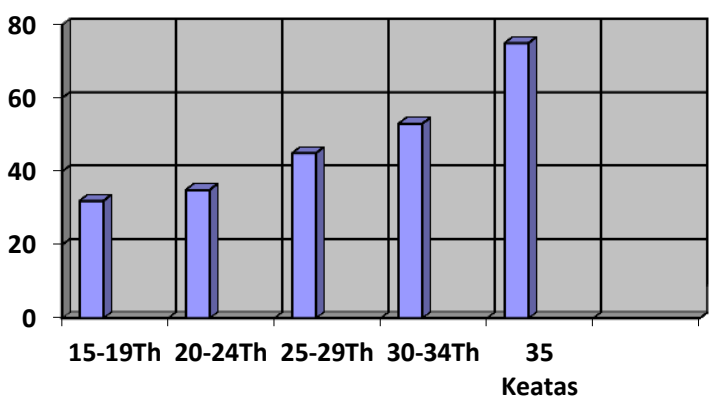

Gambar 4. Tingkat usia warga RT. 17 Desa Loa Duri Ulu

\section{Dampak Sosial}

Wilayah Desa Loa Duri Ulu, Merandai merupakan kawasan pemukiman yang cukup luas dan strategis. Desa Loa Duri Ulu terdiri dari 4 Rukun Tetangga (RT) dimana RT. 17 merupakan wilayah yang paling luas, sehingga banyak pendududk yang terdapat dalam wilayah tersebut. Diketahui bahwa jumlah penduduk untuk wilayah RT. 17 yaitu mencapai 105 Kepala keluarga (KK) yang terdiri dari 159 laki-laki dan 116 perempuan. Tingkat pendidikan warga RT. 17 Desa Loa Duri Ulu sebagian besar sampai jenjang SMA/SMK atau sederajat yaitu mencapai 54\%, untuk tingkat SD yaitu 21\%, SMP 15\%, dan untuk tingkat Perguruan Tinggi hanya mencapai 5\%, namun ada juga warga yang tidak bersekolah.

PT. Bukit Baiduri Energi melalui Pemerintah setempat atau RT ikut membantu dalam pelayanan-pelayanan masyarakat sekitar, contohnya dalam perbaikan jalan desa, pembangunan Balai Desa, pembangunan saluran drainase, memberikan pelayanan kesehatan gratis bagi warga 2 kali dalam setahun, membantu pelayanan kesehatan masyarakat (Puskesmas), membantu meringankan biaya sekolah bagi anak-anak warga, membantu sekolah-sekolah dalam perbaikan maupun meningkatkan kualitas tenaga pendidik, juga dalam pembangunan rumah ibadah bagi warga. Hal ini diperkuat dengan hasil kuesioner dari sepuluh responden.

Adapun sarana pendidikan dan sarana tempat ibadah yang ada di RT. 17 Desa Loa Duri Ulu yaitu untuk sekolah terdapat 1 Taman Kanak-kanak (TK), dan 1 Sekolah Dasar (SD), sedangkan untuk Sekolah Menengah Pertama (SMP), SMA atau sederajat serta Perguruan Tinggi di Wilayah RT. 17 belum ada. Untuk tempat ibadah di Desa Loa Duri Ulu terdapat 2 Mesjid, 2 Langgar dan 4 Gereja.

Tingkat usia warga RT. 17 yaitu 15-19 tahun berjumlah 32 orang, usia 20-24 tahun berjumlah 35 orang, 25-29 tahun berjumlah 45 orang, sedangkan usia 30-34 tahun berjumlah 53 orang, dan untuk usia 35 tahun keatas berjumlah 75 orang.

\section{Dampak Ekonomi}

Adanya kegiatan pertambangan disekitar pemukiman penduduk, tentu saja akan membawa perubahan terhadap 
pertumbuhan ekonomi di daerah tersebut. Demikian juga yang terjadi di Desa Loa Duri Ulu, Merandai, khususnya di wilayah RT. 17, dimana sebagian besar warganya menggantungkan hidupnya pada kegiatan pertambangan batubara yang dilakukan oleh PT. Bukit Baiduri Energi. Warga RT. 17 tidak semuanya bekerja, tetapi hanya sebagian kecil yang tidak memiliki pekerjaan, $90 \%$ yang bekerja dan $10 \%$ yang tidak memiliki pekerjaan. Pekerjaan warga RT. 17 Desa Loa Duri Ulu yaitu 60\% bekerja sebagai karyawan di PT. Bukit Baiduri Energi, sisanya $20 \%$ bekerja sebagai petani, dan buruh konstruksi serta galangan kapal masing-masing $10 \%$. Keadaan ini menggambarkan bahwa warga Desa Loa Duri Ulu, Merandai sangat bergantung pada pertambangan batubara yang ada di lingkungan mereka.

\section{KESIMPULAN}

Dari hasil penelitian dapat disimpulkan bahwa dampak sosial yang dirasakan oleh warga yaitu dimana pihak perusahaan memberikan kontribusi kepada masyarakat khususnya di RT 17, berupa bantuan untuk pendidikan, pelayanan kesehatan, rumah ibadah, pembangunan Balai Desa, dan pembangunan jalan desa. Sedangkan untuk dampak ekonomi yang dirasakan warga dari kegiatan pertambangan tersebut yaitu terbukanya peluang usaha bagi warga sekitar khususnya warga RT. 17, dimana sebagian besar warga RT. 17 bekerja sebagai karyawan PT. BBE.

Pihak perusahaan memberikan kesempatan kerja bagi warga sekitar, khususnya warga RT. 17 dan juga memberikan peluang usaha lain.

\section{DAFTAR PUSTAKA}

Anonim, 2018. Data Badan Pusat Statistik, Kabupaten Kutai Kartanegara dalam Angka, Tenggarong.

Harfani, E. Y. (2007). Evaluasi Pengelolaan Lingkungan PT. Bukit Baiduri Energi di Kalimantan Timur.

Haslam, S.M., 1990, River Pollution An Ecological Perspective, Belhaven Press, London.

Koesoebiono, 1979, Dasar-dasar Ekologi Umum, , IPB, Bogor.

Mahida, U.N., 1984. Pencemaran Air dan Pemanfaatan Limbah Industri., Jakarta.

Men-LH, 2003, Keputusan Menteri Negara Lingkungan Hidup Nomor 113 Tahun 2003 Tentang Baku Mutu Air Limbah Bagi Usaha dan atau Kegiatan Pertambangan, Jakarta.

Parrel, Tom, MSc., 2000, Discussion Paper, "Mining Environmental Management in Indonesia, Opportunity for Collaboration in Science and Technology.

Prijono S,. Simatupang dan Sigit,. 1992. Pengantar Pertambangan Indonesia, Asosiasi Pertambangan Indonesia, Jakarta.

Raden, I. (2010). Kajian Dampak Penambangan Batubara Terhadap Pengembangan Sosial Ekonomi dan Lingkungan di Kabupaten Kukar. Badan
Penelitian dan Pengembangan Kementerian Dalam Negeri. Jakarta.

Riduwan, (2005). Metode dan Teknik Menyusun Tesis CV. Alfabeta. Bandung.

Setiawan, Y. (2010). Pengelolaan Tambang Batubara (Studi Kasus : Kota Samarinda).

Singarimbun, M. dan Effendie, S. (1989). Metode Penelitian Survei LP3ES. Jakarta. 